\title{
Programa de Pós-Graduação em Geografia Dissertações Defendidas - Mestrado
}

\author{
Autor: Pedro Nogueira Gonçalves Diogo \\ Orientador: Cláudio Antonio G. Egler \\ Título: Ação econômica local e royalties do petróleo na Área de \\ Influência da Bacia de Campos
}

№ de páginas: 122

\section{Resumo:}

Esta dissertação se propõe a analisar as perspectivas de transformação da estrutura produtiva da Área de Influência da Bacia de Campos, a partir da intervenção econômica das prefeituras em meio a um contexto de entrada de expressivos recursos a titulo de participações governamentais na produção de petróleo e gás natural

As práticas de fomento econômico local, ainda relativamente recentes no Brasil, tornam-se uma questão crucial na nova realidade da Área de Influência da Bacia de Campos. O enriquecimento súbito das prefeituras e a perspectiva de esgotamento do petróleo e o do gás fazem com que as ações voltadas à mobilização produtiva da região assumam um caráter estratégico.

No entanto, a heterogeneidade da área de estudo, na qual convive a modernidade das empresas de Macaé com a pobreza do interior do Norte Fluminense, e o próprio conservadorismo das elites locais se colocam como desafios territoriais a uma política de desenvolvimento, tornando incerto o futuro da Área de Influência da Bacia de Campos. 